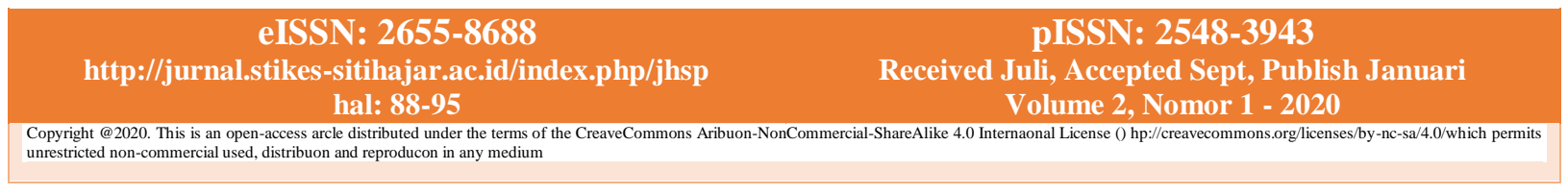

\title{
Efek Protektif Penggunaan Antiradiasi Alpha Spin Terhadap Histologi Hipokampus Tikus Putih (Rattus novergicus) Galur Sprague dawley yang Terpapar Gelombang Elektromagnetik Ponsel
}

\author{
Ahmad Rizki Dwi Prasetia ${ }^{1}$, Waluyo Rudiyanto ${ }^{1}$, Merry Indah Sari ${ }^{1}$ \\ ${ }^{1}$ Fakultas Kedokteran, Universitas Lampung \\ Email : ahmadrizkidwiprasetia@gmail.com
}

\begin{abstract}
ABSTRAK
Paparan radiasi elektromagnetik ponsel dapat menimbulkan stres oksidatif yang nantinya dapat mengakibatkan perubahan pada sel piramidal hipokampus. Perubahan ini dapat ditandai dengan adanya pengurangan jumlah sel piramidal dan adanya perubahan morfologi sel yang ditandai dengan terjadi piknosis ataupun degenerasi hidrofik pada inti sel piramidal hipokampus. Alpha Spin dapat menghambat paparan radiasi elektromagnetik ponsel melalui medan energi kuantum yang dibentuk oleh Alpha Spin. Penelitian ini bertujuan untuk mengetahui efek protektif dari penggunaan antiradiasi Alpha spin terhadap histologi hipokampus tikus putih (Rattus norvegicus) galur Sprague dawley yang terpapar gelombang elektromagnetik ponsel. Penelitian eksperimental laboratorik dengan menggunakan metode acak terkontrol dengan post test only control group design. Sampel adalah 30 ekor tikus putih yang dibagi menjadi 3 kelompok. Kelompok kontrol (K) hanya diberi makan dan minum, kelompok perlakuan 1 (P1) dipaparkan gelombang elektromagnetik ponsel dan kelompok perlakuan $2(\mathrm{P} 2)$ dipaparkan gelombang elektromagnetik ponsel dan diletakkan Alpha Spin. Paparan dilakukan 2 jam/hari selama 30 hari. Terdapat perbedaan rerata pada semua kelompok dengan nilai yang bermakna, yaitu $\mathrm{p}<0,05$. Terdapat efek protektif pemberian antiradiasi Alpha Spin terhadap gambaran histologi hipokampus tikus putih (Rattus norvegicus) galur Sprague dawley yang terpapar gelombang elektromagnetik ponsel.
\end{abstract}

Kata Kunci: Alpha Spin, Gelombang Elektromagnetik Ponsel, Hipokampus

\section{Protective Effect Of Use Alpha Spin As Ntiradiation On The Histology Of The Hippocampus On Albino Rat (Rattus novergicus) Strain Sprague dawley Exposed By Cell Phone's Electromagnetic Waves}

\begin{abstract}
Exposure to cellphone electromagnetic radiation can cause oxidative stress which can later lead to changes in the hippocampal pyramidal cells. This change can be characterized by a reduction in the number of pyramidal cells and a change in cell morphology characterized by occurrence of picnosis or hydropic degeneration in the hippocampal pyramidal cell nucleus. Alpha Spin can inhibit cell phone electromagnetic radiation exposure through the quantum energy field formed by Alpha Spin. This study aims to determine the protective effect of the use of Alpha spin antiradiation on the histology of the hippocampus of white rats (Rattus norvegicus) Sprague dawley strains exposed to mobile electromagnetic waves. Laboratory experimental research using randomized controlled methods with a post test only control group design. Samples were 30 white rats divided into 3 groups. The control group (K) was only given food and drink, the treatment group 1 (P1) was exposed to cellphone electromagnetic waves and the treatment group 2 (P2) was exposed to cellphone electromagnetic waves and placed Alpha Spin. Exposure is done 2 hours / day for 30 days. There were mean differences in all groups with a significant value, which was $\mathrm{p}<0.05$. There is a protective effect of Alpha Spin antiradiation on the histology of the hippocampus white rat (Rattus norvegicus) Sprague dawley strain that is exposed to cellphone electromagnetic waves.
\end{abstract}

Keywords: Alpha Spin, cellphone's electromagnetic waves, hippocampus 


\section{Pendahuluan}

Telepon seluler (ponsel) merupakan salah satu kebutuhan wajib manusia akan alat komunikasi pada saat ini. Telepon seluler dapat memancarkan gelombang elektromagnetik walaupun pada skala yang kecil (Enny, 2014). Telepon seluler mempunyai beragam frekuensi seperti 450 Megahertz (MHz), $800 \mathrm{MHz}, 900 \mathrm{MHz}, 1800 \mathrm{MHz}$, ataupun $1900 \mathrm{MHz}$ akan tetapi ponsel banyak yang menggunakan frekuensi $1800 \mathrm{MHz}$ (Sulaiman \& Anggriani, 2019). Penggunaan telepon seluler yang terus meningkat memungkinkan dampak radiasi yang dipaparkan telepon seluler dapat berpengaruh terhadap kesehatan tubuh manusia (Idayati, 2011).

Penggunaan ponsel dapat mengakibatkan orang mempunyai ketergantungan yang tinggi akan alat tersebut dan ketagihan itu menyebabkan orang berlama-lama saat menggunakan ponsel. Akan tetapi hal yang perlu diketahui adalah ponsel memiliki paparan gelombang elektromagnetik yang berbahaya bagi tubuh (Friedman et al., 2007). Penggunaan telepon seluler yang semakin meningkat membuat pengguna harus lebih fokus pada efek samping penggunaan ponsel tersebut (Haq, 2017).

Paparan radiasi elektromagnetik pada ponsel dalam waktu tertentu dapat menimbulkan efek negatif. Efek negatif yang dimaksudkan didapatkan saat orang menelepon dengan ponsel (Usman \& Davidson, 2017). Efek negatif penggunaan ponsel tersebut secara tidak langsung bisa meningkat seiring dengan bertambahnya pengguna ponsel serta lamanya pemakaian ponsel di setiap harinya (Hanafy et al., 2010). Adapun efek negatif tersebut berupa peningkatan aktivitas enzim NADH oksidase. Karena perubahan tersebut nantinya akan menimbulkan stres oksidatif pada hipokampus yang dapat merubah struktur organ itu sendiri serta mengakibatkan gangguan fungsi ataupun kerusakan sel pada hipokampus (Hussein et al., 2016). Dalam penelitian Hussein et al. (2016), terdapat perubahan pada otak tikus pada saat diberi paparan radiasi ponsel selama 2 jam/hari selama 3 bulan.

Diperlukan pengamatan terhadap jaringan hipokampus apabila ingin mengetahui salah satu efek negatif dari radiasi ponsel. Apabila ditemukan perubahan degeneratif sel piramidal hipokampus pada subjek penelitian (bisa berupa tikus putih) yang dipaparkan gelombang elektromagnetik telepon seluler berarti terjadi kerusakan sel pada hipokampus karena proses stres oksidatif. Perubahan degeneratif ini dapat ditandai dengan perubahan bentuk sel piramidal yang awalnya berbentuk segitiga (triangular shape) menjadi bentuk yang tidak beraturan ataupun bentuk lain, adanya pengurangan ukuran diameter serta jumlah sel piramidal hipokampus (Hussein et al., 2016). Selain itu, perubahan sel piramidal hipokampus dapat ditandai dengan terjadinya degenerasi hidrofik ataupun piknosis pada inti sel.

Alpha Spin dapat meminimalisir dan mencegah paparan gelombang elektromagnetik ponsel dengan cara membentuk medan energi kuantum. Medan energi kuantum yang dihasilkan dapat mencegah perpindahan gelombang elektromagnetik dengan cara menetralkan radiasi berbahaya yang dipaparkan oleh ponsel (Avenue, 2019). Berdasarkan uraian latar belakang tersebut, peneliti tertarik untuk melakukan penelitian dengan judul "Efek Protektif Penggunaan Antiradiasi Alpha Spin terhadap Histologi Hipokampus Tikus Putih (Rattus novergicus) Galur Sprague dawley yang Terpapar Gelombang Elektromagnetik Ponsel”.

\section{Metode Penelitian}

Penelitian ini merupakan penelitian eksperimental dengan metode rancangan post test only control group design. Penelitian ini dilakukan pada Oktober 2018 - Desember 2018 bertempat di animal house dan Laboratorium anatomi, histologi, dan patologi anatomi Fakultas Kedokteran Universitas Lampung.

Penelitian ini menggunakan sampel tikus putih (Rattus norvegicus) jantan galur Sprague dawley yang dipilih dengan metode simple random sampling. Berdasarkan perhitungan sampel menggunakan rumus Frederer dan ditambah dengan proporsi drop out 
$10 \%$, jumlah sampel minimal yang dibutuhkan sebanyak 30 tikus. Tikus yang digunakan menjadi sampel harus memenuhi kriteria inklusi yaitu tikus putih (Rattus norvegicus) galur Sprague dawley jantan berumur 8-12 minggu dengan berat badan 150-250 gram. Tikus tidak bisa dijadikan sampel apabila memenuhi kriteria eksklusi yaitu terdapat kelainan anatomis, tikus tidak sehat, terdapat penurunan berat badan lebih dari $10 \%$ setelah masa adaptasi di laboraturium, tikus mati selama masa penelitian, dan terdapat eksudat yang tidak normal dari mata, mulut, anus, genital setelah masa adaptasi.

Tikus ini dibagi menjadi 3 kelompok yaitu 1 kelompok kontrol (K) dan 2 kelompok perlakuan (P1 dan P2). Sebelum diberi perlakuan, tikus diaklimatisasi terlebih dahulu pada lingkungan tempat dilakukan perlakuan. Kelompok kontrol hanya diberi pakan dan minuman. Kelompok P1 diberikan pakan, minuman, dan perlakuan berupa paparan gelombang elektromagnetik ponsel selama 2 jam/hari dalam 30 hari. Kelompok P2 diberikan pakan, minuman, dan perlakuan berupa paparan gelombang elektromagnetik ponsel dan penggunaan Alpha Spin selama 2 jam/hari dalam 30 hari.

Setelah perlakuan selama 30 hari, tikus kemudian diterminasi dengan anestesi lalu dilakukan laparotomi untuk mengambil organ hipokampus. Setelah hipokampus diambil, tikus dikuburkan. Hipokampus difiksasi dengan menggunakan formalin $10 \%$ sebelum dilakukan pembuatan preparat dengan pewarnaan hematoksilin-eosin. Setelah preparat dibuat, dilakukan pembacaan mikroskopis pada perbesaran 400x dalam 5 pandang untuk setiap preparat.

Penilaian perubahan sel piramidal hipokampus dihitung dari skor perubahan morfologi $(0=$ gambaran sel normal, $1=$ terdapat degenerasi hidrofik, $2=$ terdapat piknosis $)$ ditambah skor perubahan jumlah sel $(0=$ jumlah sel normal, $1=$ terdapat pengurangan jumlah sel sebanyak $>10 \%)$ dengan total skor $0-3(0=$ sel normal, $1=$ perubahan sel derajat ringan, $2=$ perubahan sel derajat sedang, $3=$ perubahan sel derajat berat). Setelah data diperoleh, dilakukan uji normalitas data dengan Shapiro-Wilk dan uji Levene untuk melihat data homogen atau tidak. Apabila data terdistribusi normal dan homogen maka dilakukan uji hipotesis One Way ANOVA dan dilanjutkan dengan uji Post Hoc Bonfferoni.

\section{Hasil Penelitian}

Berikut ini merupakan hasil skoring perubahan sel piramidal hipokampus dari masingmasing kelompok pada 5 lapang pandang preparat.

Tabel 1. Kelompok Kontrol (K)

\begin{tabular}{ccccccc}
\hline Sampel & LP 1 & LP 2 & LP 3 & LP 4 & LP 5 & Rerata LP \\
\hline $\mathbf{1}$ & 1 & 0 & 0 & 0 & 1 & 0,4 \\
$\mathbf{2}$ & 1 & 1 & 0 & 0 & 0 & 0,4 \\
$\mathbf{3}$ & 1 & 1 & 0 & 1 & 0 & 0,6 \\
$\mathbf{4}$ & 0 & 0 & 1 & 0 & 1 & 0,4 \\
$\mathbf{5}$ & 1 & 0 & 1 & 1 & 1 & 0,8 \\
$\mathbf{6}$ & 1 & 1 & 1 & 0 & 0 & 0,6 \\
$\mathbf{7}$ & 0 & 1 & 0 & 1 & 0 & 0,4 \\
$\mathbf{8}$ & 0 & 0 & 0 & 0 & 1 & 0,2 \\
$\mathbf{9}$ & 1 & 0 & 0 & 0 & 0 & 0,2 \\
$\mathbf{1 0}$ & 1 & 1 & 0 & 0 & 0 & 0,4 \\
\hline
\end{tabular}

Dari tabel diatas didapatkan rerata skor pada kelompok kontrol adalah 0,44 dengan gambaran histologi yang tampak normal. Tidak ditemukan adanya perubahan morfologi sel berupa degenerasi hidrofik ataupun piknosis dan jumlah sel masih banyak akan tetapi pada beberapa gambaran terdapat pengurangan jumlah sel piramidal hipokampus. 
Tabel 2. Kelompok Perlakuan 1 (P1)

\begin{tabular}{ccccccc}
\hline Sampel & LP 1 & LP 2 & LP 3 & LP 4 & LP 5 & Rerata LP \\
\hline $\mathbf{1}$ & 2 & 2 & 1 & 2 & 2 & 1,8 \\
$\mathbf{2}$ & 1 & 2 & 1 & 1 & 1 & 1,2 \\
$\mathbf{3}$ & 2 & 2 & 2 & 2 & 2 & 2 \\
$\mathbf{4}$ & 2 & 2 & 2 & 2 & 3 & 2,2 \\
$\mathbf{5}$ & 3 & 3 & 2 & 2 & 2 & 2,4 \\
$\mathbf{6}$ & 2 & 2 & 3 & 2 & 3 & 2,4 \\
$\mathbf{7}$ & 2 & 2 & 2 & 2 & 3 & 2,2 \\
$\mathbf{8}$ & 2 & 1 & 3 & 2 & 2 & 2 \\
$\mathbf{9}$ & 2 & 1 & 2 & 1 & 2 & 1,6 \\
$\mathbf{1 0}$ & 3 & 2 & 2 & 3 & 3 & 2,6 \\
\hline
\end{tabular}

Pada P1 didapatkan rerata skor 2,04. Pada gambaran histologinya, kepadatan sel nampak sedikit lebih renggang dan terdapat pengurangan jumlah sel. Jumlah sel piramidal kelompok P1 nampak lebih sedikit bila dibandingkan dengan kelompok kontrol dan kelompok P2. Nampak terdapat piknosis pada inti sel di beberapa sel piramidal.

Tabel 3. Kelompok Perlakuan 2 (P2)

\begin{tabular}{ccccccc}
\hline Sampel & LP 1 & LP 2 & LP 3 & LP 4 & LP 5 & Rerata LP \\
\hline $\mathbf{1}$ & 1 & 2 & 2 & 1 & 1 & 1,4 \\
$\mathbf{2}$ & 2 & 1 & 2 & 3 & 1 & 1,8 \\
$\mathbf{3}$ & 1 & 2 & 2 & 2 & 0 & 1,4 \\
$\mathbf{4}$ & 3 & 2 & 2 & 1 & 2 & 2 \\
$\mathbf{5}$ & 0 & 2 & 2 & 3 & 1 & 1,6 \\
$\mathbf{6}$ & 0 & 3 & 1 & 2 & 3 & 1,8 \\
$\mathbf{7}$ & 1 & 1 & 2 & 2 & 1 & 1,4 \\
$\mathbf{8}$ & 2 & 3 & 2 & 2 & 0 & 1,8 \\
$\mathbf{9}$ & 1 & 2 & 2 & 1 & 1 & 1,4 \\
$\mathbf{1 0}$ & 1 & 1 & 2 & 2 & 2 & 1,6 \\
\hline
\end{tabular}

Pada gambaran histologinya, kepadatan sel pada kelompok P2 sedikit lebih renggang serta terdapat pengurangan jumlah sel piramidal. Pada kelompok P2, jumlah selnya lebih sedikit bila dibandingkan dengan kelompok kontrol namun masih lebih banyak dibanding dengan kelompok P1. Nampak terdapat piknosis pada inti sel di beberapa sel piramidal tetapi tidak sebanyak pada kelompok P1.

Untuk mengetahui apakah terdapat efek protektif penggunaan Alpha Spin terhadap gambaran histologi hipokampus tikus, maka dilakukan uji hipotesis One Way ANOVA. Sebelum uji hipotesis, dilakukan uji normalitas Shapiro-Wilk terlebih dahulu. Hasil uji normalitas menunjukkan data terdistribusi normal ( $p>0,05)$. Setelah itu dilakukan uji Levene untuk melihat data homogen atau tidak. Hasil uji Levene menunjukkan $\mathrm{p}=0,058(\mathrm{p}>0,05)$ yang berarti data homogen. Selanjutnya dilanjutkan dengan uji. Karena syarat uji parametrik sudah terpenuhi, maka uji hipotesis One Way ANOVA dapat dilakukan dan dilanjutkan dengan Post hoc Bonfferoni. Nilai p pada uji One Way Anova yaitu $\mathrm{p}=0,000(\mathrm{p}<0,05)$ sehingga dapat disimpulkan terdapat efek protektif pemberian antiradiasi Alpha Spin terhadap gambaran histologi hipokampus tikus putih. Untuk mengetahui perbedaaan antar kelompok perlakuan maka dilakukan analisis Post Hoc Bonfferoni yang dapat dilihat pada tabel 4. 
Tabel 4. Hasil Analisis Post Hoc Bonfferoni

\begin{tabular}{ccc}
\hline Kelompok & Kelompok Pembanding & Nilai Signifikansi (p) \\
\hline K & P1 & 0,000 \\
& P2 & 0,000 \\
P1 & K & 0,000 \\
& P2 & 0,010 \\
P2 & P & 0,000 \\
& P1 & 0,010 \\
\hline
\end{tabular}

Hasil analisis Post Hoc Bonfferoni yang dilakukan menunjukkan nilai signifikansi p<0,05 pada semua kelompok sehingga dapat disimpulkan terdapat perbedaan bermakna pengaruh efek protektif penggunaan Alpha Spin terhadap histologi hipokampus tikus putih pada setiap kelompok perlakuan yaitu K-P1, K-P2, dan P1-P2.

$\mathrm{K}$

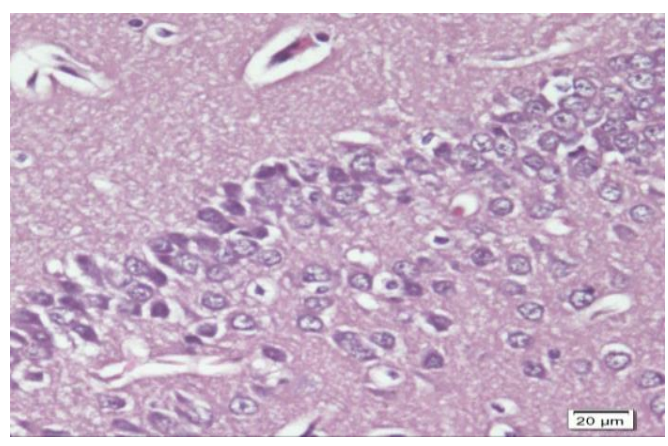

P1

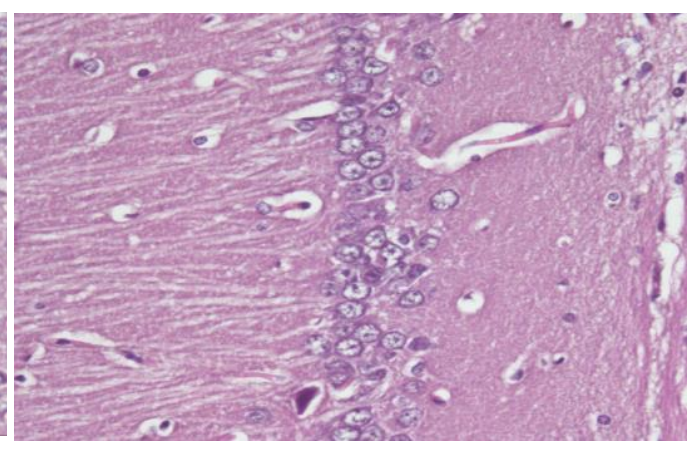

P2

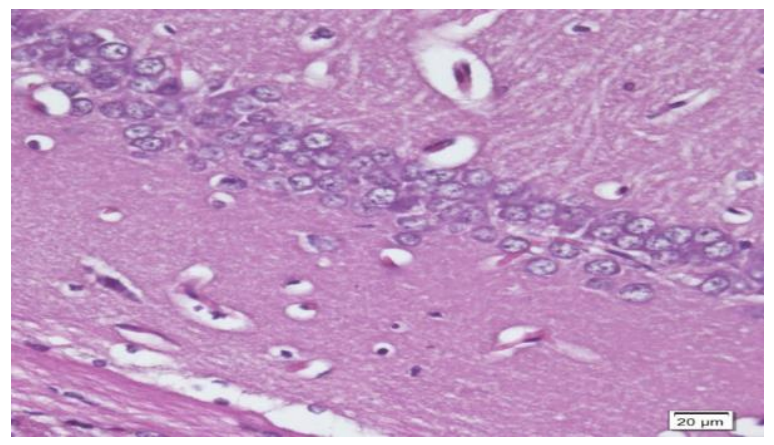

Gambar 1. Gambaran Histologi Kelompok Kontrol (K), Kelompok Perlakuan 1 (P1), dan Kelompok Perlakuan 2 (P2).

\section{Pembahasan}

Pada hasil pengamatan secara mikroskopis didapatkan nilai rerata kelompok kontrol sebesar 0,44 yang berarti sel piramidal hipokampus masih tergolong normal karena pada kelompok kontrol hanya terdapat pengurangan jumlah sel di beberapa lapang pandang dan tidak diikuti dengan perubahan morfologi sel yang berupa proses piknosis ataupun degenerasi hidrofik pada inti sel. Hasil normal ini terjadi karena pada kelompok kontrol tidak diberikan stresor yang dapat menyebabkan perubahan pada sel piramidal hipokampus tikus putih sehingga kelompok kontrol dijadikan sebagai acuan.

Pada kelompok P1 memiliki nilai rerata perubahan sel piramidal hipokampus sebesar 2,04 yang berarti terjadi perubahan derajat sedang. Pada sel piramidal hipokampus terdapat perubahan berupa pengurangan jumlah sel lebih dari $10 \%$ dari jumlah normalnya ataupun 
perubahan morfologi sel ataupun gabungan dari kriteria pengurangan jumlah sel dan perubahan morfologi. Pada gambaran mikroskopisnya terjadi piknosis inti sel dan jarang ditemukan degenerasi hidrofik. Perubahan pada sel piramidal ini dapat dikarenakan gelombang elektromagnetik ponsel secara langsung meningkatkan aktivitas NADH oksidase yang nantinya meningkatkan produksi ROS. Produksi ROS yang berlebihan menyebabkan stres oksidatif (Achudume et al., 2010). Stres oksidatif tersebutlah yang membuat perubahan morfologi inti sel dan pengurangan jumlah sel piramidal hipokampus.

Paparan radiasi elektromagnetik pada ponsel dalam waktu tertentu dapat menimbulkan efek negatif yang didapatkan saat orang menelepon dengan ponsel (Usman \& Davidson, 2017). Dalam penelitian Achudume et al. (2010), paparan GEM ponsel pada tikus putih dapat meningkatkan stres oksidatif yang ditandai dengan penurunan sistem antioksidan pada otak.

Pada penelitian Hussein et al. (2016), dilakukan penelitian dengan memaparkan gelombang elektromagnetik ponsel pada 40 ekor tikus jantan selama 2 jam/hari dalam 3 bulan. Adapun didapatkan hasil berupa terdapat perubahan degeneratif sel piramidal hipokampus yang ditandai dengan berubahnya bentuk awal yang berupa bentuk segitiga menjadi bentuk yang tidak beraturan ataupun bentuk lain. Perubahan tersebut mengakibatkan gangguan fungsi ataupun kerusakan sel piramidal hipokampus.

Pada penelitian Prayoga (2015), dilakukan penelitian dengan memaparkan gelombang elektromagnetik ponsel selama 21 hari. Pada penelitian ini didapatkan hasil bahwa paparan tersebut memberikan pengaruh berupa defisit dalam memori kerja dan perubahan perilaku yang menandakan kerusakan dari hipokampus tikus putih.

Pada kelompok P2 memiliki nilai rerata perubahan sel piramidal hipokampus sebesar 1,62. Kriteria perubahan sama seperti pada kelompok P1 akan tetapi skor rerata perubahan kelompok P2 lebih rendah daripada kelompok P1. Perubahan tersebut juga terjadi karena adanya paparan gelombang elektromagnetik ponsel yang sama seperti pada kelompok P1, akan tetapi pada kelompok P2 diberikan antiradiasi Alpha Spin sehingga perubahan yang terjadi pada sel piramidal hipokampus dapat dikurangi. Stres oksidatif pada kelompok P2 tetap ada. Hal inilah yang menyebabkan tetap adanya perubahan berupa pengurangan jumlah sel piramidal ataupun perubahan morfologi sel ataupun gabungan dari kedua kriteria tersebut walaupun tidak sebanyak pada kelompok P1.

Apabila terdapat peningkatan stres oksidatif pada hipokampus maka akan terjadi perubahan pada sel piramidalnya. Akan tetapi, stres oksidatif dapat dikurangi dengan penggunaan Alpha Spin (Hanafy et al., 2010). Alpha Spin dapat mengurangi efek negatif dari paparan gelombang elektromagnetik ponsel, akan tetapi pada penggunaannya masih dapat menimbulkan perubahan pada sel piramidal hipokampus tikus. Oleh karena itu, lokasi dalam meletakkan ponsel dan Alpha Spin, pemilihan jenis ponsel ataupun faktor-faktor lain yang dapat memengaruhi sel piramidal hipokampus harus lebih diperhatikan.

Pada uji analisis Post Hoc Bonfferoni pada kelompok K dan P1 didapatkan nilai $\mathrm{p}$ yaitu 0,000 atau $\mathrm{p}<0,05$ yang artinya terdapat perbedaan yang bermakna antara kelompok $\mathrm{K}$ dan P1 sehingga paparan gelombang elektromagnerik ponsel dapat mengakibatkan perubahan sel piramidal hipokampus. Pada uji Post Hoc Bonfferoni pada kelompok K dan P2 didapatkan nilai $\mathrm{p}$ yaitu 0,000 atau $\mathrm{p}<0,05$ yang menunjukkan adanya perbedaan yang bermakna antara kelompok K dan P2 yang berarti pemberian Alpha Spin terhadap kelompok P2 dapat mencegah gelombang elektromagnetik ponsel yang dapat mengubah sel piramidal hipokampus menjadi abnormal. Pada uji Post Hoc Bonfferoni pada kelompok P1 dan P2 didapatkan nilai $\mathrm{p}$ yaitu 0,000 atau $\mathrm{p}<0,05$ yang menunjukkan adanya perbedaan yang bermakna antara kelompok P1 dan P2.

Sel piramidal hipokampus dikatakan mengalami perubahan apabila terdapat kriteria seperti pengurangan jumlah sel serta perubahan morfologi sel piramidal hipokampus. Untuk penelitian lebih lanjut dapat diteliti kriteria lain dari perubahan sel piramidal hipokampus 
seperti proses terjadinya kariolisis. Pada penelitian ini juga diketahui hipokampus mengalami perubahan bila terpapar gelombang elektromagnetik ponsel dan perubahan akan diminimalisir dengan adanya Alpha Spin. Untuk penelitian lebih lanjut juga dapat meneliti organ atau jaringan lain dari hewan coba seperti darah agar diketahui apakah bagian tersebut mengalami perubahan atau masih terproteksi oleh Alpha Spin.

\section{Kesimpulan}

Terdapat efek protektif pemberian antiradiasi Alpha Spin terhadap gambaran histologi hipokampus tikus putih (Rattus norvegicus) galur Sprague dawley yang terpapar gelombang elektromagnetik ponsel.

\section{Referensi}

Achudume A, Onibere B, Aina F, Tchokossa P. (2010). Induction of oxidative stress in male rats subchronically exposed to electromagnetic fields at non-thermal intensities. JEMAA, 2(8): 482-487.

Avenue JMO. (2019). Body and home quantum energy field - frequency optimizer and harmonizer, http://alphaspin.co., diperoleh tanggal 2 Januari 2020.

Bahteran R. (2013). Analisis klasifikasi ponsel (hp) terhadap paparan radiasi gelombang elektromagnetik [skripsi]. Mataram: Universitas Mataram.

Enny. (2014). Efek samping penggunaan ponsel. Gema Teknologi, 17(4):178-183.

Eser O, Songur A, Aktas C, Karavelioglu E, Caglar V, Aylak F, et al. (2013). The effect of electromagnetic radiation on the rat brain: an experimental study. Turkish Neurosurgery, 23(6):707-715.

Friedman J, Kraus S, Hauptman Y, Schiff Y, Seger R. (2007). Mechanism of short- term ERK activation by electromagnetic fields at mobile phone frequencies. Biochem $J$, 405(3):559-568.

Hanafy LK, Karam SH, Saleh A. (2010). The adverse effects of mobile phone radiation on some visceral organs. Research Journal of Medicine and Medical Sciences, 5(1): 95-99.

Haq I. (2017). Gsm technology: architecture, security, and future challenges. International Journal of Science Engineering and Advance Technology, 5(1):1-6.

Hussein S, El-saba A, Galal MK. (2016). Biochemical and histological studies on adverse effects of mobile phone radiation on rat' $\mathrm{s}$ brain. Journal of Chemical Neuroanatomy, 78:10-19.

Idayati R. (2011). Pengaruh radiasi handphone terhadap kesehatan. Jurnal Kedokteran Syiah Kuala, 11(2):115-120.

Noviarini Y, Makiyah SNN. (2010). Pengaruh pajanan gelombang telepon seluler terhadap struktur histologi hipokampus pada mencit (Mus musculus). Mutiara Medika, 10(2):123-127.

Nurahayati I. (2014). Pengaruh radiasi handphone terhadap otak. JKèm-U, 6(17):29-32.

Prayoga PR. (2015). Pengaruh paparan gelombang elektromagnetik kronik terhadap memori kerja dan perubahan perilaku pada tikus putih (Rattus novergicus) galur Sprague dawley [skripsi]. Bandar Lampung: Universitas Lampung.

Sulaiman, Anggriani. (2019). Pengaruh Penggunaan Infra Red di Posyandu Lansia Desa Lama. Pelita Masyarakat, 1(1):46-54.

Sutyarso. (2011). Dampak paparan gelombang elektromagnetik ponsel. National Institute of Enviromental Health Science, 10:31-35.

Swamardika A. (2009). Pengaruh radiasi gelombang elektromagnetik terhadap kesehatan manusia. Majalah Ilmiah Teknologi Elektro, 8(1)106-109.

Tarigan TRP, Gani UA, Rajagukguk M. (2013). Studi tingkat radiasi medan elektromagnetik 
yang ditimbulkan oleh telepon selular. Jurnal Teknik Elektro Universitas Tanjungpura, $1(1): 1-8$.

Tyagi A, Duhan M, Bhatia D. (2011). Effect of mobile phone radiation on brain activity : gsm vs cdma. IJSTM, 2(2): 1-5.

Usman, M., Davidson, J. (2017). Cellphones: The silent killer or just a hoax. Mendon: Mendon Cottage Books.

Wargo J, Taylor HS, Alderman N, Wargo L, Bradley JM, Addis S. (2012). Cell phone: the cell phone problem. Technology-Exposure-Health Effects, 3-64. 